\title{
Nutrient subsidies delivered by seabirds to mangrove islands
}

\author{
M. F. Adame ${ }^{1,2, *}$, B. Fry ${ }^{1}$, J. N. Gamboa ${ }^{2}$, J. A. Herrera-Silveira ${ }^{2}$ \\ ${ }^{1}$ Australian Rivers Institute, Griffith University, Nathan, 4111, QLD, Australia \\ ${ }^{2}$ CINVESTAV-IPN, Unidad Mérida, Km 6, Antigua Carretera a Progreso, Cordemex 97310, Mérida, Yucatán, México
}

\begin{abstract}
In nutrient-poor landscapes, external nutrient subsidies are important for sustaining local production. Seabirds can transport marine nutrients in the form of guano to terrestrial and coastal ecosystems where they can relieve nutrient limitation. We assessed whether seabirds provide nutrient subsidies to mangrove islands that are strongly limited by phosphorus (P) in the Yucatan Peninsula. Our hypotheses were: (1) seabirds transport nutrients to mangrove islands, (2) mangroves use marine-derived nutrients and (3) nutrient inputs are higher during the nesting season. We chose 6 mangrove islands within a coastal lagoon: 2 with no birds, 2 with temporary birds and 2 with permanent bird colonies. On each, we measured forest structure and soil characteristics $(\mathrm{P}, \mathrm{pH}$, salinity and organic matter) for 3 seasons (dry, wet and trade wind season). We collected leaves (green and senescent) to determine P content and resorption efficiency as a measurement of nutrient limitation. Green leaves were also sampled for $\delta^{13} \mathrm{C}$ and $\delta^{15} \mathrm{~N}$ to determine nutrient origin. Results show that islands with permanent bird colonies have the highest soil nutrients, which are used by the mangrove trees and relieve some of their nutrient limitation. Nutrient inputs were homogenously distributed through the sediment column, although a decrease in $\mathrm{P}$ and an increase in the N:P ratio in the first $20 \mathrm{~cm}$ suggests bacterial consumption. Bird nutrient inputs are seasonal, with highest inputs during the nesting season. This study shows an example in which marine-derived nutrients could be important for production of coastal mangrove islands.
\end{abstract}

KEY WORDS: Wetlands · Phosphorus · Subsidies · Nutrient limitation · Isotopes · Guano

\section{INTRODUCTION}

A spatial subsidy is a donor resource from one habitat to a second habitat that results in increased productivity (Polis et al. 1997). Marine and coastal production is generally subsidized by terrigenous material (litter, detritus and dissolved carbon and nutrients) that is transported seawards through rivers and runoff (Polis et al. 1997). The importance of a subsidy is largely dependent on productivity gradients, i.e. the larger the gradient, the stronger the impact of the subsidy is (Polis et al. 1997). Thus, in nutrient-poor landscapes, external subsidies are very important for sustaining local production.

Mangrove forests thrive on the edge of terrestrial and marine ecosystems, sometimes in nutrient poor conditions (Robertson \& Alongi 1992). In karstic landscapes, such as the Yucatan Peninsula, mangroves receive nitrates from groundwater (Herrera-Silveira 1996, ArandaCicerol et al. 2006), but phosphorus (P) availability is very low, mainly due to its precipitation in the presence of calcium carbonate. In such a nutrient-deprived environment, marine sources are likely to be important in relieving phosphorus limitation 
(Lovelock et al. 2011). For example, nutrients from the Cabo Catoche upwelling located between the Caribbean Sea and the Gulf of Mexico provide an important nutrient resource to algae and mangroves of the western Yucatan Peninsula (Enriquez et al. 2010, Adame et al. 2013b).

The basic components of foodwebs - nutrients, detritus and organisms - all cross spatial boundaries and promote connectivity among ecosystems (Polis et al. 1997). Birds can transport large quantities of nutrients from one habitat to another in the form of guano and carcasses. Nutrients from bird guano can promote primary production and modify species composition in terrestrial and aquatic systems (Powell et al. 1991, Maron et al. 2006). For example, seabirds that feed in productive waters from the Gulf of California deposit large quantities of guano in the adjacent desert causing an increase in animal biomass (Polis \& Hurd 1996). Seabird guano can be used by terrestrial plants and significantly change the nitrogen $(\mathrm{N})$ cycle within an island (Schmidt et al. 2004). Similarly, seabirds can have a significant effect on mangroves, causing an increase of up to $33 \%$ in leaf $\mathrm{N}$ (Onuf et al. 1977).

Mangroves are an important habitat for many bird species (Nagelkerken et al. 2008) and support permanent and migrant bird colonies (Lefebvre \& Poulin 1996). There are 182 wetlands of international importance identified by the Ramsar Convention in the world, 31 of them in Mexico, that have mangrove forests. Despite the strong link between birds and mangrove health (Holguin et al. 2006), this is the first study to spatially and temporally test when and how mangroves are subsidized by nutrients derived from seabirds.

The present study was conducted in the Celestun Biosphere Reserve, in Yucatan, Mexico. This coastal lagoon is an important site for temporary and migratory birds, many of which roost and breed in mangrove islands in the lagoon. The aim of the project was to test whether seabirds provided nutrient subsidies to mangrove islands, whether mangroves used these marine-derived nutrients and whether these subsidies relieved nutrient limitation. Our hypotheses were: (1) seabirds provide marine subsidies to mangrove islands, (2) mangroves use marine-derived nutrients and (3) nutrient subsidies are higher during the nesting season.

\section{MATERIALS AND METHODS}

\section{Study site}

Celestun is a coastal lagoon located off the northwest coast of the Yucatan Peninsula $\left(20^{\circ} 45^{\prime} \mathrm{N}, 90^{\circ}\right.$ $20^{\prime} \mathrm{W}$ ). It is approximately $22.5 \mathrm{~km}$ long and $1.25 \mathrm{~km}$ wide and has a total area of $28.1 \mathrm{~km}^{2}$ (Fig. 1). The lagoon is $460 \mathrm{~m}$ wide in the south, where it opens into the Gulf of Mexico. The substrate of the area is karstic, rich in carbonates and highly permeable. There are no surface rivers in the area; however, there are numerous springs that discharge freshwater into the lagoon, mostly in the northern part (Perry et al. 2009).

The climate of the region is classified as warm semi-arid, with low precipitation that falls mainly during the wet season (García \& Mosiño 1992). The mean temperature is $28.5^{\circ} \mathrm{C}$, with a maximum temperature of $35^{\circ} \mathrm{C}$ (August) and a minimum of $21^{\circ} \mathrm{C}$ (February). The mean annual precipitation is $760 \mathrm{~mm}$. The region has 3 seasons: a dry season

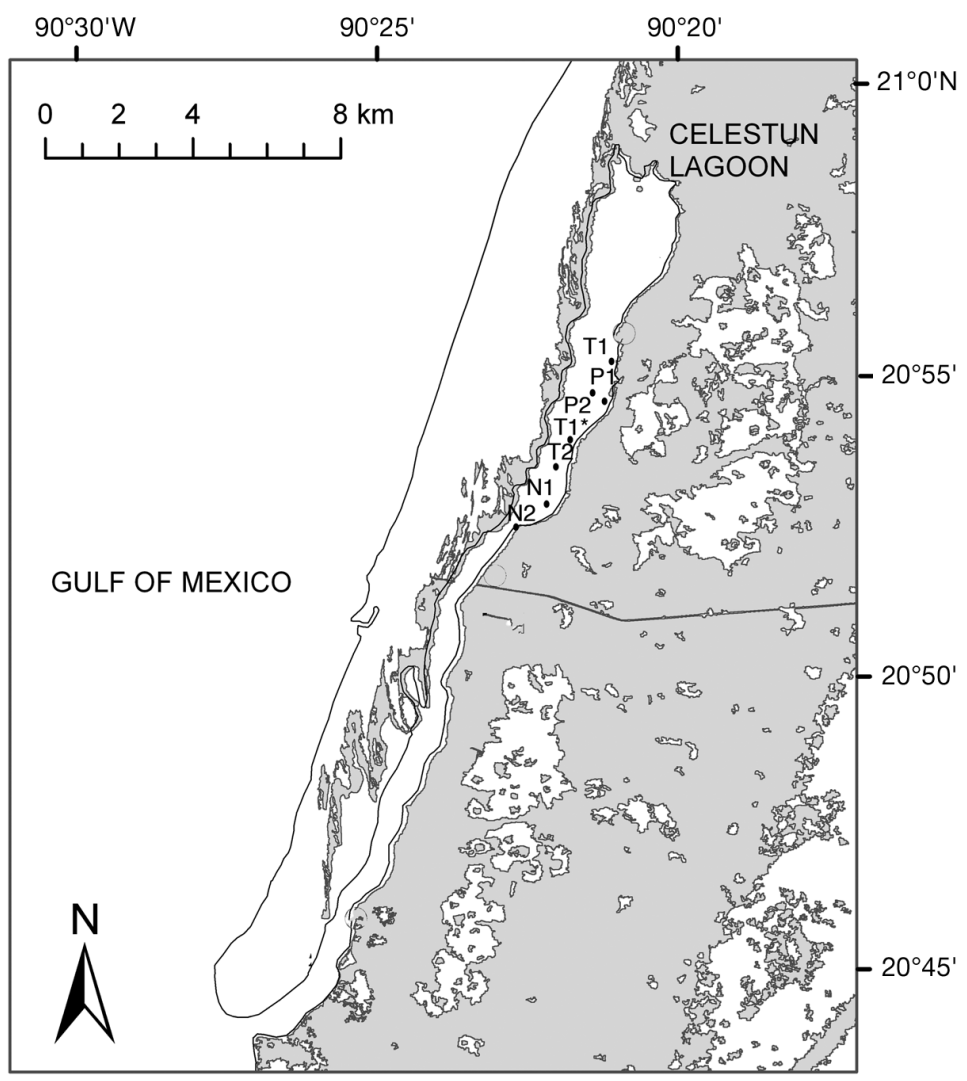

Fig. 1. Celestun Biosphere Reserve and sampling islands within the lagoon: $\mathrm{P}=$ permanent bird colonies; $\mathrm{T}=$ temporary bird colonies and $\mathrm{N}=$ no birds. $\mathrm{T}^{*}$ is an island that was sampled as a substitute of $\mathrm{T} 1$ during the wet season when the latter could not be reached. Shaded areas show the extent of mangrove forests (CONABIO 2009) 
(March to May), a wet season with high rainfall (>500 mm; June to October) and the so-called 'trade wind season' locally known as 'nortes season' (November to February). The trade wind season is characterized by strong winds $\left(>80 \mathrm{~km} \mathrm{~h}^{-1}\right)$, low rainfall (20 to $60 \mathrm{~mm}$ ) and relatively low temperatures $\left(<22^{\circ} \mathrm{C}\right)$ imposed by low-pressure air masses coming from the north. During the wet season, the lagoon is regularly impacted by tropical storms.

Celestun Lagoon is microtidal (tidal amplitude $<2 \mathrm{~m}$ ) and is bordered by extensive mangrove forests (19437 ha) (CONABIO 2009) dominated by Laguncularia racemosa in the inner zone of the lagoon, Rhizophora mangle and Avicennia germinans in the middle zone and $A$. germinans at the mouth of the lagoon (Zaldívar-Jiménez et al. 2004).

Celestun is a Biosphere Reserve and experiences relatively low human impact. However, shrimp and crab fishing is common. Ecotourism, such as bird watching, is also a popular activity within the reserve with the American flamingo Phoenicopterus ruber attracting the most visitors to the Reserve. Celestun is also an important feeding and migration site for 274 species of birds, 98 of which are migratory species (DUMAC 2012). Many resident and migratory birds nest and roost in small mangrove islands located in the north of the lagoon (Fig. 1), especially during the trade wind season, which corresponds to the northern hemisphere winter and, thus, the arrival of migratory birds from northern latitudes.

For this study, we selected 6 mangrove islands that represented a gradient of bird occurrence. The first 2 islands (P1 and P2) had permanent bird colonies throughout the year, comprised mainly of breeding colonies of frigate birds Fregata magnificens, cormorants Phalacocorax auritus and egrets from the genus Egretta and Ardea, with P1 having higher bird densities compared to P2. Bird densities on these islands have been reported to be $>500$ individuals per island (DUMAC 2012). The second 2 islands (T1, T2) had fewer and temporary birds. On these islands, pelicans Pelecanus occidentalis and cormorants $P$. auritus were regularly found roosting, but not nesting, with T1 having higher bird densities compared to T2. Finally, the last 2 islands (N1, N2) had the lowest occurrence of birds $(<10$ individuals at any one time). Of these 2 islands, N2 was slightly connected to the mainland by a narrow stretch of trees. For logistical reasons we were not able to reach T1 during the wet season, and, as a substitute, a comparable island with similar numbers of birds was sampled during the wet season (Fig. 1, T1*). All the islands were semicircular in shape, ranged from a diameter of $40 \mathrm{~m}$ (T2) to $285 \mathrm{~m}$ (P1) (see Table 1) and were dominated by trees of $R$. mangle and $L$. racemosa.

\section{Methodology}

Sampling was conducted during 3 seasons: the wet (July 2011), trade wind season (December 2011 to January 2012) and dry season (April to May 2012). The trade wind season corresponded to the largest migrating colonies and the nesting period for many bird species in the lagoon. Forest structure (biomass, species composition, tree density) was measured at least once for each island. Soil physicochemical characteristics (total $\mathrm{P}, \mathrm{pH}$, salinity, soil depth, organic matter content) were measured for each season. Leaves (green and senescent) were collected during the 3 seasons in order to determine $\mathrm{P}$ concentration and resorption efficiency as a measure of nutrient limitation. Additionally, green leaves were sampled for $\delta^{15} \mathrm{~N}$ analyses to determine whether mangroves were using nutrients derived from seabirds, and for $\delta^{13} \mathrm{C}$ to determine possible variations in photosynthetic activity. We expected to observe the effect of nutrient additions (i.e. bird guano) in the mangrove trees within the first 6 mo after nutrient addition (Lovelock et al. 2011). Details of sampling methodologies are given below.

\section{Forest structure}

Species composition and tree density were measured with transects set across the islands (50 to $80 \mathrm{~m}$ ) using the point-centred quarter method (PCQM+) (Dahdouh-Guebas \& Koedam 2006). Allometric equations by Smith \& Whelan (2006) were applied to determine tree biomass using the diameter at $1.3 \mathrm{~m}$ of height (diameter at breast height) for L. racemosa and A. germinans, and the diameter of the main branch above the highest prop root for $R$. mangle, following guidelines by Dahdouh-Guebas \& Koedam (2006).

\section{Soil physicochemical characteristics}

Salinity was measured within each island and season from interstitial water extracted from the ground at a depth of $30 \mathrm{~cm}$ using a syringe and an acrylic tube. The syringe was rinsed twice before obtaining a clear water sample, from which salinity was meas- 
ured using an YSI-30 multiprobe sensor (YSI, Xylem). Soil surface $\mathrm{pH}$ was measured for each island and season using a pH-meter (Digi-Sense, Cole Parmer Instrumentation). Triplicate samples were taken for both salinity and $\mathrm{pH}$.

Three surface soil samples $(10 \mathrm{~cm}$ depth $)$ were taken with a minicore of $50 \mathrm{~cm}^{3}$ (3 $\mathrm{cm}$ in diameter) at each island, for each season. To calculate bulk density, the sediment was weighed after being ovendried at $60^{\circ} \mathrm{C}$. Bulk density was calculated as the dry weight of the sample divided by its volume. For assessment of soil organic matter (OM), $2 \mathrm{~g}$ of dry sediment was combusted at $550^{\circ} \mathrm{C}$ for $4 \mathrm{~h}$ and weighed. The OM was calculated as the difference between the pre- and post-combusted sample (Heiri et al. 2001; analytical error of $2 \%$ ). Soil P (total P as orthophosphate) was measured using the methodology described by Aspila et al. (1976) and Parsons et al. (1984) (analytical error of $0.01 \%$ ).

Four soil cores $1 \mathrm{~m}$ in length were sampled from each island (28 cores in total) at the end of the wet season (September 2014). The cores were taken with a semi-cylindrical peat auger chamber with a $6.4 \mathrm{~cm}$ radius. Each core was systematically divided and subsampled at 5 depths $(0-10 \mathrm{~cm}, 10-20 \mathrm{~cm}, 20-$ $30 \mathrm{~cm}, 30-50 \mathrm{~cm}$ and $50-100 \mathrm{~cm})$. Each sample was analysed for P (Aspila et al. 1976, Parsons et al. 1984), $\mathrm{N}$ and carbon (C) content (EA-IRMS, Serco System, Griffith University) (analytical errors of $2 \%$ for $\mathrm{C}$ and $0.1 \%$ for $\mathrm{N}$ ).

Soil depth was measured at 5 randomly selected locations within each island during the dry season. The depth was estimated using an aluminium rod that was inserted into the ground. The distance from the surface to the soil horizon where the substrate changed (from mangrove peat to sand) was recorded.

\section{Nutrient concentration in leaf tissue}

Leaves were sampled during the 3 seasons from 3 mangrove species: $R$. mangle, $L$. racemosa and A. germinans. At each island, 5 to 10 young fully expanded leaves exposed to the sun and 5 to 10 senescent leaves were sampled. Leaves were pooled in one sample per island, species and category (green/ senescent). Leaf $P$ concentration was measured using a methodology similar to that used for soil $\mathrm{P}$ (Aspila et al. 1976, Parsons et al. 1984). Leaf $\mathrm{N}$ and $\mathrm{C}$ concentrations were measured in leaves of $R$. mangle and L. racemosa in an elemental-analyser (EA-IRMS, Serco System, Griffith University).

\section{Phosphorus resorption efficiency}

We collected yellow senescent leaves that were still attached to the mangrove tree. As a measure of nutrient limitation, we calculated nutrient resorption efficiency ( $\mathrm{RE} \%$ ) as the percentage of $\mathrm{P}$ recovered from senescing leaves before leaf fall (Chapin \& Van Cleve 1989):

$\mathrm{RE} \%=\frac{\mathrm{P} \text { green leaves }-\mathrm{P} \text { senescent leaves }}{\mathrm{P} \text { senescent leaves }} \times 100$

Leaf isotope values

Leaf isotope values for $\delta^{13} \mathrm{C}$ and $\delta^{15} \mathrm{~N}$ were measured from pooled samples of green leaves of $R$. mangle and $L$. racemosa from each island and season. Samples were measured in an elemental-analyser isotope ratio mass spectrometer (EA-IRMS, Sercon System, Griffith University; analytical errors of $0.1 \%$ for $\delta^{13} \mathrm{C}$ and $0.2 \%$ for $\delta^{15} \mathrm{~N}$ ).

\section{Data analyses}

Differences in forest structure, soil physicochemical characteristics, leaf nutrients and resorption efficiency were tested with analysis of variance (ANOVA), where bird occurrence (permanent vs. temporal vs. no birds) was the fixed effect of the model. Normality was assessed using normality probability plots and Shapiro-Wilks tests. If data were not normal (e.g. soil P), they were transformed ( $\log x$ or $1 / x)$. When the transformations were not sufficient to achieve normality (e.g. $\mathrm{pH}$ ), differences among categories were analysed using $k$-independent samples with a Kruskall-Wallis test. Differences in soil physicochemical characteristics among seasons were tested using repeated measures ANOVA, where site was the repeated measurement over time. The substitute island $\left(\mathrm{T} 1{ }^{*}\right)$ used during the wet season for $\mathrm{T} 1$ (see 'Study site') was not included in the temporal analysis. The assumption of sphericity required for repeated measures ANOVA was tested using a Mauchly's test of sphericity. When the assumption of sphericity was violated (soil P), the GreenhouseGeiseer correction was used. Comparison among vegetation types and sites for significant tests was assessed using Scheffé post-hoc tests. Statistical tests were performed with SPSS Statistics (version 21, IBM). Throughout the article, data are reported as mean \pm standard error. 


\section{RESULTS}

\section{Forest structure}

Forest structure of mangrove islands is shown in Table 1. Islands with permanent bird colonies (P1 and P2) and temporary bird colonies (T1) had a higher percentage of Avicennia germinans (18 to $20 \%$ ) compared to the other islands (T2, N1, N2: $<12 \%$ ) (Table 1).

\section{Soil physicochemical characteristics}

The mean salinity of the islands throughout the year was $37.1 \pm 2.6 \mathrm{ppt}$. Salinity was significantly different among islands and ranged from a site mean of $28.0 \mathrm{ppt}$ on island N2 to $44.9 \mathrm{ppt}$ on island T1 (Table 2). Overall, the highest salinities were meas- ured on islands with permanent or temporary bird colonies $\left(F_{2,17}=8.07, \mathrm{p}=0.0040\right)$. Salinity was lowest during the trade wind season with a mean of $34.3 \pm$ 2.7 ppt $\left(F_{2,8}=5.60, \mathrm{p}=0.030\right)$. Soil $\mathrm{pH}$ had a mean value of $7.0 \pm 0.1$ and was similar among sites (chisquare $=3.91, \mathrm{df}=2$, asymptotic significance $=0.141$ ) and seasons $\left(F_{2,8}=0.65, \mathrm{p}=0.55\right)$.

Soil OM was similar among islands with different bird occurrence $\left(F_{2,17}=1.12, \mathrm{p}=0.35\right)$ but carbonate content was lower on islands with permanent bird colonies compared to those without birds $\left(F_{2,12}=5.66\right.$, $\mathrm{p}=0.026)$. Soil $\mathrm{OM}$ was significantly lower during the wet season $\left(F_{2,28}=8.49, \mathrm{p}=0.001\right)$.

Mean soil P for all islands was $0.151 \pm 0.065 \%$, with highest values measured on P1 $(0.373 \pm 0.299 \%)$ and lowest on N2 $(0.026 \pm 0.016 \%)$. Soil P was significantly higher on islands with permanent birds compared to islands with temporary or no birds $\left(F_{2,18}=\right.$ 6.29, $\mathrm{p}=$ 0.010) (Fig. 2). Soil $\mathrm{P}$ was also significantly higher during the trade wind season $(0.345 \pm 0.086 \%)$ and wet season $(0.113 \pm 0.026 \%)$ compared to the dry season $(0.022 \pm 0.006 \%)\left(F_{2,34}=12.64\right.$, $\mathrm{p}=0.002$ ) (Fig. 2).

Throughout the sediment column, $\mathrm{P}$ was highest and $\mathrm{C}: \mathrm{P}, \mathrm{N}: \mathrm{P}$ and $\mathrm{C}: \mathrm{N}$ were lowest on islands with permanent bird colonies (Fig. 3). The distribution of $\mathrm{N}, \mathrm{P}$ and $\mathrm{C}$ concentration with depth was nearly homogeneous. However, there was a rapid decrease of $\mathrm{P}(\%)$ and a slight increase in the $\mathrm{N}: \mathrm{P}$ ratio on islands with permanent bird colonies in the first $20 \mathrm{~cm}$ of the sediment column.

\section{Nutrient concentration in leaves} have permanent bird colonies (P1, P2) (>500 ind. at any one time), 2 have temporary birds (T1, T2) and the other 2 rarely have birds (N1, N2) $(<10$ ind.). The values are mean \pm SE for samples taken in triplicate during 3 seasons: wet season, trade wind season and dry season (each site, $\mathrm{n}=9$ ). Soil depth was measured on each island during the dry season $(n=5)$. Salinity was significantly higher and carbonate content significantly lower on islands with permanent or temporary birds compared to islands with no birds. Superscripts denote significant differences $(\mathrm{p}<0.05)$

\begin{tabular}{|ccccccc|}
\hline Site & pH & $\begin{array}{c}\text { Salinity } \\
(\mathrm{ppt})\end{array}$ & $\begin{array}{c}\text { Organic } \\
\text { matter } \\
(\%)\end{array}$ & $\begin{array}{c}\text { Carbonate } \\
\text { content } \\
(\%)\end{array}$ & $\begin{array}{c}\text { Bulk } \\
\text { density } \\
\left(\mathrm{g} \mathrm{cm}^{-3}\right)\end{array}$ & $\begin{array}{c}\text { Soil } \\
\text { depth } \\
(\mathrm{cm})\end{array}$ \\
\hline $\mathrm{P} 1$ & $7.0 \pm 0.3$ & $37.6 \pm 2.0^{\mathrm{a}}$ & $30.8 \pm 7.1$ & $21.1 \pm 7.2^{\mathrm{a}}$ & $0.4 \pm 0.0$ & $191 \pm 2$ \\
$\mathrm{P} 2$ & $6.6 \pm 0.2$ & $41.4 \pm 1.8^{\mathrm{a}}$ & $30.1 \pm 4.4$ & $15.3 \pm 3.0^{\mathrm{a}}$ & $0.3 \pm 0.1$ & $190 \pm 2$ \\
T1 & $7.3 \pm 0.1$ & $44.9 \pm 4.5^{\mathrm{a}}$ & $27.0 \pm 7.1$ & $24.1 \pm 5.5^{\mathrm{ab}}$ & $0.4 \pm 0.0$ & $187 \pm 6$ \\
$\mathrm{~T} 2$ & $7.0 \pm 0.1$ & $38.8 \pm 1.7^{\mathrm{a}}$ & $21.0 \pm 5.3$ & $30.1 \pm 3.5^{\mathrm{ab}}$ & $0.4 \pm 0.1$ & $161 \pm 4$ \\
$\mathrm{~N} 1$ & $7.2 \pm 0.1$ & $32.0 \pm 4.1^{\mathrm{b}}$ & $23.0 \pm 2.3$ & $31.7 \pm 0.1^{\mathrm{b}}$ & $0.4 \pm 0.0$ & $163 \pm 6$ \\
$\mathrm{~N} 2$ & $6.7 \pm 0.1$ & $28.0 \pm 2.7^{\mathrm{b}}$ & $25.1 \pm 4.8$ & $31.1 \pm 2.4^{\mathrm{b}}$ & $0.4 \pm 0.1$ & $185 \pm 2$ \\
\hline
\end{tabular}

Mangrove leaf phosphorus concentrations were highest on islands with permanent birds, although the significance was only marginal $\left(F_{2,18}=3.01\right.$, $\mathrm{p}=0.079$ ). By species, leaf $\mathrm{P}$ in $A$. germinans trees was highest on islands with permanent bird colonies $\left(F_{2,16}=\right.$ 3.73, $\mathrm{p}=0.050$ ) (Table 3). Leaves of Rhizophora mangle had a mean $\mathrm{P}$ concentration of $0.130 \pm 0.006 \%$, Laguncularia racemosa of $0.132 \pm$ $0.010 \%$ and A. germinans of $0.172 \pm$ $0.010 \%$. Phosphorus in leaves was significantly higher in the trade wind 


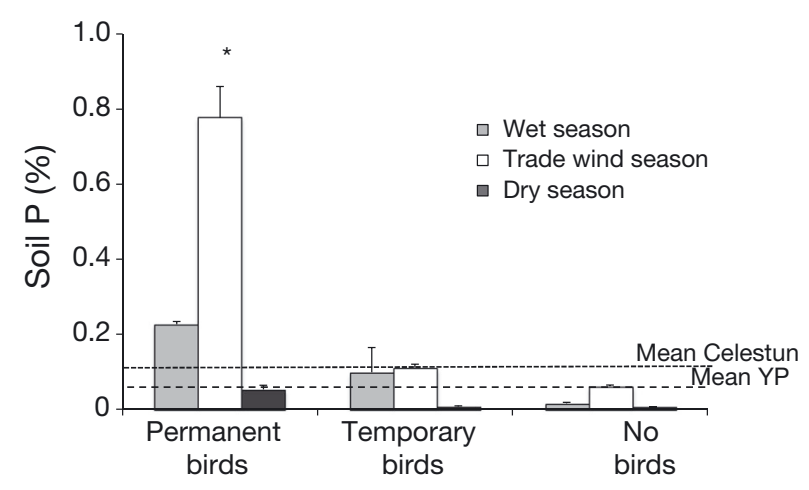

Fig. 2. Soil phosphorus (P) concentrations (\%) on islands with permanent bird colonies $(n=2)$, on islands with temporary birds $(\mathrm{n}=2)$ and islands with no birds $(\mathrm{n}=2)$. Samples were taken during 3 seasons: wet season, trade wind season and dry season. Each value is the mean of soil phosphorus for 2 islands, 3 soil samples per island. Soil $\mathrm{P}$ is highest on islands with permanent bird colonies $(p=0.010)$. Dashed lines represent the soil mean concentration for mangroves in Celestun (Herrera-Silveira et al. 2009) and the Yucatan Peninsula (YP) (Adame et al. 2013b) season compared to the wet and dry season $\left(F_{2,30}=\right.$ $6.603, p=0.004)$. Leaf $C: P$ ratio was lowest on islands with permanent bird colonies $\left(F_{2,18}=5.116, \mathrm{p}=0.020\right)$ and during the north trade wind season $\left(F_{2,6}=11.272\right.$, $\mathrm{p}=0.009$ ).

The leaf $\mathrm{N}$ concentration mean was $1.34 \pm 0.05 \%$ for $R$. mangle and $1.57 \pm 0.17 \%$ for $L$. racemosa. Leaf $\mathrm{N}$ in $R$. mangle was highest on islands with permanent bird colonies $\left(F_{2,18}=8.32, \mathrm{p}=0.040\right)$. Leaf $\mathrm{N}$ in $L$. racemosa was significantly higher in the trade wind season $\left(F_{2,10}=4.06, \mathrm{p}=0.050\right)$ compared to the other seasons. Mean leaf $\mathrm{C}$ concentrations in mangrove leaves were $39.6 \pm 3.9 \%(35.8 \pm 0.5 \%$ for $R$. mangle and $43.5 \pm 3.6 \%$ for L. racemosa), with significantly higher values on islands without birds $\left(F_{2,18}=16.04, \mathrm{p}<0.001\right)$ compared to those with permanent or temporary bird colonies. Consequently, the C:N ratio was significantly lowest at sites with permanent bird colonies $\left(F_{2,18}=10.88, \mathrm{p}=0.001\right)$. The overall $\mathrm{C}: \mathrm{N}$ mean ratio was $27.4 \pm 1.1$. Leaf $\mathrm{C}$ was similar among seasons.
$\% \mathrm{P}$
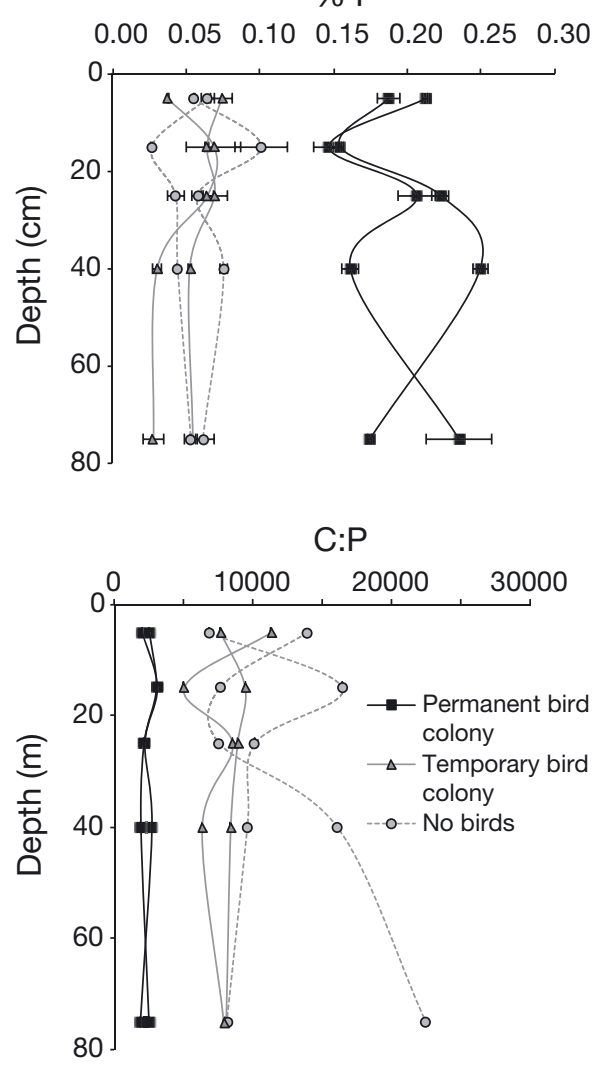

\section{Phosphorus resorption efficiency (RE\%)}

The RE\% was significantly lower at sites with permanent bird colonies compared to those with temporary or no birds $\left(F_{2,16}=4.70, \mathrm{p}=\right.$ 0.029 ) and was lowest in the wet season $\left(F_{2,8}=6.69, \mathrm{p}=0.020\right)$. Thus, mangroves on islands with permanent bird colonies and during the wet season reabsorb fewer nutrients from their senescent leaves, which suggests lower phosphorus limitation on these islands during periods of rainfall.

\section{Leaf nutrient origin}

Mean isotopic values of leaves of $R$. mangle were $-29.9 \pm 0.1 \%$ and $11.1 \pm 0.8 \%$ or $\delta^{13} \mathrm{C}$ and $\delta^{15} \mathrm{~N}$, respectively; leaves of $L$. racemosa were $-29.4 \pm 0.5 \%$ and $10.0 \pm$ $0.7 \%$, respectively. Leaf $\delta^{15} \mathrm{~N}$ of $R$. mangle was higher for islands with permanent birds compared to islands with temporary or no birds

Fig. 3. Soil phosphorus (\%P) and N:P, C:P and C:N ratios in sediment cores $(0$ to $100 \mathrm{~cm})(\mathrm{n}=4$ cores per island) on islands with permanent bird colonies, on islands with temporary birds and islands with no birds. Error bars are SE

\begin{abstract}
$\left(F_{2,18}=9.77, \mathrm{p}=0.002\right)$. Addition-
\end{abstract}


Table 3. Phosphorus (P), nitrogen (N) and carbon (C) concentrations (\%) and P resorption efficiency (RE\%) in leaves of mangroves of Rhizophora mangle (Rm), Laguncularia racemosa ( $\mathrm{Lr}$ ) and Avicennia germinans (Ag). Leaves were collected during 2010 and 2011 for 3 seasons (wet season, trade wind season and dry season) from 6 islands: 2 with permanent bird colonies, 2 with temporary birds and 2 with no birds. na = data not available due to small sample size. Superscripts notate significant differences of mean values among sites (uppercase) and differences for a single species among sites (lowercase)

\begin{tabular}{|c|c|c|c|c|c|c|}
\hline & $\% \mathrm{P}$ & $\% \mathrm{~N}$ & $\% \mathrm{C}$ & $\mathrm{C}: \mathrm{N}$ & $\mathrm{C}: \mathrm{P}$ & $\mathrm{RE} \%$ \\
\hline \multicolumn{7}{|c|}{ Permanent bird colonies } \\
\hline$R m$ & $0.14 \pm 0.01$ & $1.5 \pm 0.1^{\mathrm{a}}$ & $33.9 \pm 0.4$ & $20.3 \pm 1.1$ & $250 \pm 9$ & $55.3 \pm 7.1$ \\
\hline$L r$ & $0.15 \pm 0.01$ & $1.6 \pm 0.0$ & $38.3 \pm 0.1$ & $24.7 \pm 0.2$ & $365 \pm 83$ & $31.5 \pm 15.2$ \\
\hline$A g$ & $0.21 \pm 0.01^{\mathrm{a}}$ & na & na & na & na & 23.7 \\
\hline Mean & $0.16 \pm 0.01$ & $1.5 \pm 0.1^{\mathrm{A}}$ & $33.9 \pm 0.4^{\mathrm{A}}$ & $22.4 \pm 1.8^{\mathrm{A}}$ & $260 \pm 10$ & $42.3 \pm 5.5^{\mathrm{A}}$ \\
\hline \multicolumn{7}{|c|}{ Temporary bird colonies } \\
\hline$R m$ & $0.13 \pm 0.01$ & $1.3 \pm 0.1^{\mathrm{b}}$ & $35.2 \pm 0.6$ & $27.3 \pm 1.7$ & $313 \pm 12$ & $67.1 \pm 4.3$ \\
\hline$L r$ & $0.13 \pm 0.01$ & $1.5 \pm 0.3$ & $47.0 \pm 7.1$ & $31.5 \pm 0.5$ & $365 \pm 83$ & $61.7 \pm 8.4$ \\
\hline$A g$ & $0.16 \pm 0.01^{b}$ & na & na & na & na & $62.4 \pm 8.7$ \\
\hline Mean & $0.14 \pm 0.01$ & $1.2 \pm 0.0^{\mathrm{B}}$ & $35.2 \pm 0.1^{\mathrm{A}}$ & $30.1 \pm 0.3^{\mathrm{B}}$ & $339 \pm 26$ & $62.3 \pm 3.4^{\mathrm{B}}$ \\
\hline \multicolumn{7}{|c|}{ No birds } \\
\hline$R m$ & $0.12 \pm 0.00$ & $1.2 \pm 0.1^{\mathrm{b}}$ & $36.6 \pm 0.7$ & $29.9 \pm 1.2$ & $332 \pm 7$ & $60.4 \pm 6.9$ \\
\hline$L r$ & $0.11 \pm 0.02$ & $1.4 \pm 0.3$ & $45.3 \pm 7.8$ & $32.2 \pm 0.8$ & $477 \pm 39$ & $59.1 \pm 6.6$ \\
\hline$A g$ & $0.16 \pm 0.02^{\mathrm{b}}$ & na & na & na & na & 45.9 \\
\hline Mean & $0.14 \pm 0.01$ & $1.3 \pm 0.0^{\mathrm{B}}$ & $38.3 \pm 0.1^{\mathrm{B}}$ & $29.7 \pm 0.3^{\mathrm{B}}$ & $405 \pm 72$ & $58.1 \pm 3.0^{\mathrm{B}}$ \\
\hline
\end{tabular}
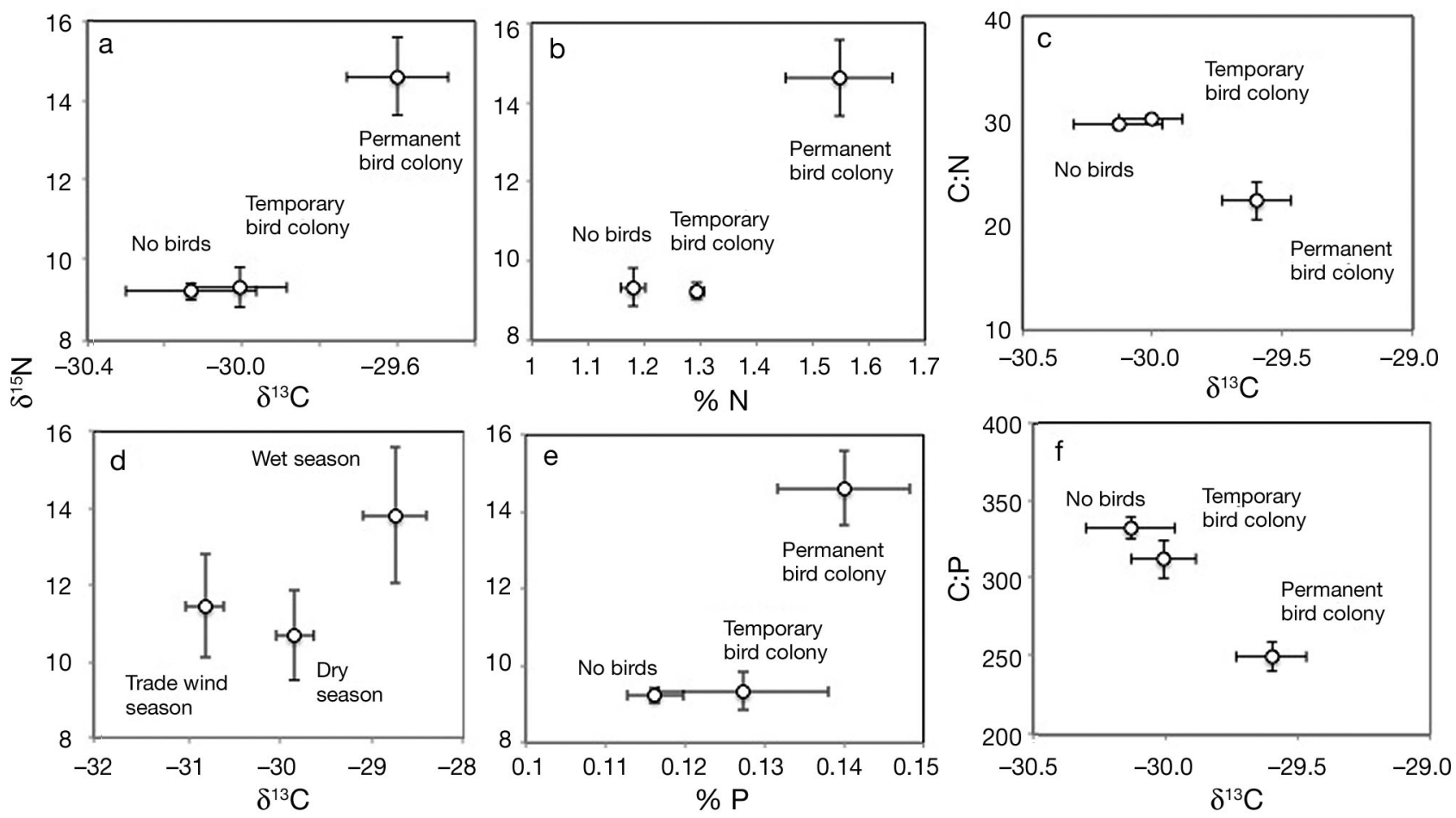

Fig. 4. Characteristics of leaves of Rhizophora mangle on 6 islands: 2 with permanent bird colonies, 2 with temporary birds and 2 with no birds. (a) $\delta^{13} \mathrm{C}$, (b) $\% \mathrm{~N}$ and (e) $\% \mathrm{P}$ against $\delta^{15} \mathrm{~N}$ and $\delta^{13} \mathrm{C}$ against (c) C:N and (f) C:P. Leaf $\delta^{15} \mathrm{~N}$ and $\mathrm{N}$ were significantly higher for islands with birds compared to islands with temporary or no birds $\left(F_{2,18}=9.77, \mathrm{p}=0.002 ; F_{2,18}=8.32, \mathrm{p}=0.04\right.$, respectively). (d) Characteristics of leaves of $R$. mangle during 3 seasons: wet season, trade wind season and dry season. Leaf $\delta^{13} \mathrm{C}$ values were significantly highest in the wet season $\left(F_{2,10}=13.33, \mathrm{p}=0.002\right)$

ally, $\delta^{13} \mathrm{C}$ values in $R$. mangle were significantly higher in the wet season compared to those during the north trade wind season $\left(F_{2,10}=13.33, \mathrm{p}=\right.$
0.002) (Fig. 4). Leaf $\delta^{13} \mathrm{C}$ and $\delta^{15} \mathrm{~N}$ for L. racemosa were not significantly different among sites or seasons. 


\section{DISCUSSION}

The results from this study showed that seabirds have a significant impact on mangrove islands within a karstic oligotrophic lagoon. Islands where bird colonies are permanent have high soil nutrient inputs. The influence of seabirds is seasonal, with highest inputs during the nesting season (trade wind season) when soil $\mathrm{P}$ concentrations are up to 8 times higher than the regional mean. Because mangroves in this lagoon are nutrient limited (Adame et al. 2012), the large marine-derived inputs have consequences on their physiology. Mangroves with permanent bird colonies are relieved of some of their P limitation and their leaves are enriched in $\mathrm{N}$, and have reduced $\mathrm{C}: \mathrm{N}$ and $\mathrm{C}: \mathrm{P}$ ratios. Additionally, islands with permanent bird colonies could have higher production rates, as indicated by higher leaf $\delta^{13} \mathrm{C}$ values.

High soil $\mathrm{P}$ concentrations on islands with permanent bird colonies were measured throughout the sediment column (1 $\mathrm{m}$ deep). This suggests that seabirds have influenced the biogeochemistry of these mangrove islands for a long time. Increase in soil $\mathrm{P}$ has been associated with an increase in root and litterfall production in Celestun (Adame et al. 2013b, 2014). Litterfall within the islands where bird $P$ inputs are high were enriched in P. As mangrove soil in this region is mainly composed of organic material derived from the trees themselves (McKee et al. 2007), an increase in soil $P$ increases the input of organic material rich in $\mathrm{P}$ to the soil, and therefore accentuates the differences in soil $\mathrm{P}$ among islands.

While the distribution of $\mathrm{P}, \mathrm{N}$ and $\mathrm{C}$ throughout the sediment column was predominantly homogeneous, there was an interesting pattern at the soil surface. On the islands with permanent bird colonies, soil $\mathrm{P}$ rapidly decreased in the first $20 \mathrm{~cm}$, and the N:P ratio slightly increased. Bacteria in mangrove soils can be abundant (Alongi 1988), and their abundance has been associated with high phosphorus inputs (Adame et al. 2012). Thus, soil P enrichment by seabirds could potentially favor not only trees, but also the bacteria communities within the mangrove soil.

Leaf mean $\delta^{13} \mathrm{C}$ for leaves of Rhizophora mangle was $-29.9 \pm 0.2 \%$ and for Laguncularia racemosa was $-29.4 \pm 0.5 \%$, values that are similar to those measured in other studies (e.g. -26 to -27 for Australia, Lovelock et al. $2011 ;-27$ for Belize, Wooller et al. 2003). We found that in trees of $R$. mangle, $\delta^{13} \mathrm{C}$ was higher on islands with permanent bird colonies and during the wet season. Higher $\delta^{13} \mathrm{C}$ might imply higher $\mathrm{CO}_{2}$ assimilation rates, which result in lower discrimination of heavier carbon, and thus $\delta^{13} \mathrm{C}$ enrichment. Higher $\delta^{13} \mathrm{C}$ could also indicate decreased stomatal conductance due to higher interstitial salinity (McKee et al. 2002) and/or higher leaf $\mathrm{N}$ (Cordell et al. 1999). Enriched values of $\delta^{13} \mathrm{C}(-22 \%)$ in terrestrial forests have also been found in areas near bird colonies (Wainright et al. 1998). The results from Celestun suggest that mangrove productivity is highest on islands with bird guano inputs and during the wet season (tree reproductive season), a result that is in accordance with root and litterfall production of mangroves in Celestun (Adame et al. 2013b, 2014).

Mean $\delta^{15} \mathrm{~N}$ was $11.1 \pm 0.8$ and $10.0 \pm 0.7 \%$, for $R$. mangle and L. racemosa respectively. The $\delta^{15} \mathrm{~N}$ values were highest on islands with permanent bird colonies. While $\delta^{15} \mathrm{~N}$ values of mangrove leaves can be affected by plant and microbial fractionation (Fry et al. 2000, Mckee et al. 2002), the simplest explanation is that mangroves with seabirds are utilizing $\mathrm{N}$ derived from guano $\left(\delta^{15} \mathrm{~N}\right.$ from seabirds is usually between 14 and $17 \%$, Wainright et al. 1998). Mangroves with leaves containing high $\delta^{15} \mathrm{~N}(\sim 13 \%)$ can indicate nutrient enrichment and/or anthropogenic nutrient pollution (Fry et al. 2000, Costanzo et al. 2001); in comparison, mangrove leaves with little nutrient enrichment have values around 5 to $7 \%$ (Fry et al. 2000). The elevated $\delta^{15} \mathrm{~N}$ in the mangrove islands of Celestun could indicate sewage and N pollution derived from groundwater discharges into the lagoon (Herrera-Silveira \& Morales-Ojeda 2009), but considering the proximities of the sampled islands and the differences in $\delta^{15} \mathrm{~N}$ and bird occurrence among them, it is most likely that high $\delta^{15} \mathrm{~N}$ on islands with permanent colonies indicates $\mathrm{N}$ derived from seabirds. Similar results have been found in Belize, where mangrove leaves on islands where frigate birds nest had low C:N ratios (32 to 46) and $\delta^{15} \mathrm{~N}$ values were between 9.1 and $12.3 \%$, similar to those measured in a frigate bird feather $(14.0 \%)$ (Wooller et al. 2003). Also, islands in Australia with high seabird concentrations were enriched with $\mathrm{N}$ and had $\delta^{15} \mathrm{~N}$ values of about $9.9 \%$ (Schmidt et al. 2004).

The change in $\delta^{15} \mathrm{~N}$ among islands in Celestun Lagoon was small $(\sim 5 \%)$ compared to the large C:N ratio difference among them $(\sim 8)$, which indicates that $\mathrm{N}$ limitation was not strong. This result confirms previous findings which suggest that most mangroves in Celestun Lagoon and around Yucatan are P, not N, limited (Adame et al. 2012). Finally, we also found that $\delta^{15} \mathrm{~N}$ values were not significantly different on islands with temporary bird colonies compared to those with no birds. This result supports the 
idea that $\mathrm{N}$ is not limited on these islands and that the $\mathrm{N}$ added by birds is lower than background $\mathrm{N}$ reservoirs. After several hundred years of bird fertilization and $\mathrm{P}$ limitation, background $\mathrm{N}$ may build up on these islands and we would expect the $\delta^{15} \mathrm{~N}$ value to finally be higher as the whole biogeochemistry shifts to a more bird-fertilized system.

While the difference in leaf $\delta^{13} \mathrm{C}$ and $\delta^{15} \mathrm{~N}$ was clear in $R$. mangle, it was not significant for L. racemosa. This could mean that there are different nutrient responses for different mangrove species, or most likely a result of sampling bias. The leaves of $R$. mangle were much easier to sample compared to those of $L$. racemosa. Trees of $R$. mangle were very common around the islands, and leaves fully exposed to the sun were easily handpicked from the boat. In contrast, leaves of $L$. racemosa were only found deep within the islands and were collected by climbing up into the canopy of the trees, which occasionally made it difficult to acquire leaves that were fully exposed to the sun. This could have resulted in a less robust set of samples for $\delta^{13} \mathrm{C}$ and $\delta^{15} \mathrm{~N}$ for L. racemosa compared to those for $R$. mangle.

In conclusion, mangroves in Celestun Lagoon appear to be strongly influenced by seabirds. As birds select specific islands to nest and roost, they modify their environment by adding nutrients to the soil, especially $\mathrm{P}$, favoring litterfall production (Adame et al. 2013b), root production (Adame et al. 2014), soil organic carbon accumulation (Adame et al. 2013a) and probably island expansion. These conditions - elevated soil, high nutrients and high interstitial salinity - can favor the occurrence of trees of Avicennia germinans, a species which birds usually select for nesting in the region (Marra et al. 1998) and which is considered to represent late successional stages of mangrove forests (Lugo \& Snedaker 1974, Chen \& Twilley 1998). This study supports the idea that mangrove health is strongly linked to bird populations (Holguin et al. 2006) and that birds can act as ecosystem engineers modifying their environment by increasing soil fertility (Sekercioglu 2006). Additionally, these results suggest strong marine-terrestrial connectivity as seabirds transport nutrients from the relatively nutrient-rich marine ecosystem and subsidize the nutrient-poor coastal landscape.

Acknowledgements. We thank the Mexican Council of Science and Technology (CONACyT), the Research Centre and Postgraduate Studies of the National Polytechnic Institute (CINVESTAV, Mérida) and the Australian Rivers Institute at Griffith University. We are grateful for field support to the National Commission for Natural Protected Areas (CONANP). We thank Ileana Osorio for laboratory assis- tance, Juan Caamal for field assistance and Eduardo Galicia and Prof. Stuart Bunn for reviewing and commenting on the manuscript. The work was partially supported by a grant from the National Commission on Biodiversity (CONABIO FN009).

\section{LITERATURE CITED}

Adame MF, Reef R, Herrera-Silveira JA, Lovelock CE (2012) Sensitivity of dissolved organic carbon exchange and sediment bacteria to water quality in mangrove forests. Hydrobiologia 691:239-253

Adame MF, Kauffman JB, Medina I, Gamboa JN and others (2013a) Carbon stocks of tropical coastal wetlands within the karstic landscape of the Mexican Caribbean. PLoS ONE 8:e56569

Adame MF, Zaldívar-Jiménez A, Teutli C, Caamal JP and others (2013b) Drivers of mangrove litterfall within a karstic region affected by frequent hurricanes. Biotropica 45:147-154

Adame MF, Teutli C, Santini NS, Caamal JP, ZaldívarJiménez A, Hernández R, Herrera-Silveira JA (2014) Root biomass and production of mangroves surrounding a karstic oligotrophic coastal lagoon. Wetlands 34: 479-488

Alongi DM (1988) Bacterial productivity and microbial biomass in tropical mangrove sediments. Microb Ecol 15: 59-79

ArandaCicerol N, Herrera-Silveira JA, Comín FA (2006) Nutrient water quality in a tropical coastal zone with groundwater discharge, northwest Yucatan, Mexico. Estuar Coast Shelf Sci 68:445-454

Aspila KI, Agemian H, Chau SY (1976) A semi-automated method for detemination of inorganic, organic and total phosphate in sediments. Analyst 101:187-197

Chapin FSI, Van Cleve K (1989) Approaches to studying nutrient uptake use and loss in plants. In: Pearcy RW, Ehleringer J, Mooney HA, Rundel PW (eds) Plant physiological ecology. Field methods and instrumentation. Chapman and Hall, London, p 185-207

> Chen R, Twilley RR (1998) A gap dynamic model of mangrove forest development along gradients of soil salinity and nutrient resources. J Ecol 86:37-51

CONABIO (Comisión nacional para el conocimiento y uso de la biodiversidad) (2009) Manglares de México: extensión y distribución, 2nd edn. CONABIO, Mexico City

> Cordell S, Goldstein G, Meinzer FC, Handley LL (1999) Allocation of nitrogen and carbon in leaves of Metrosideros polymorpha regulates carboxylation capacity and $\delta 13 \mathrm{C}$ along an altitudinal gradient. Funct Ecol 13: $811-818$

> Costanzo SD, O'Donohue MJ, Dennison WC, Loneragan NR, Thomas M (2001) A new approach for detecting and mapping sewage impacts. Mar Pollut Bull 42:149-156

$>$ Dahdouh-Guebas F, Koedam N (2006) Empirical estimate of the reliability of the use of the Point-Centred Quarter Method (PCQM): solutions to ambiguous field situations and description of the PCQM+ protocol. For Ecol Manage 228:1-18

DUMAC (Ducks Unlimited Mexico) (2012) www.dumac.org/ dumac/habitat/esp/qsomos05.htm (accessed April 2013)

Enriquez C, Meriño-Tapia IJ, Herrera-Silveira JA (2010) Dispersion in the Yucatan coastal zone: implications for red tide events. Cont Shelf Res 30:127-137 
Fry B, Bern AL, Ross MS, Meeder JF (2000) $\delta 15 \mathrm{~N}$ studies of nitrogen use by the red mangrove, Rhizophora mangle L. in South Florida. Estuar Coast Shelf Sci 50:291-296

García E, Mosiño P (1992) Los climas de México, 2nd edn. Geography Institute, Mexican National Autonomous University (UNAM), Mexico City

> Heiri O, Lotter AF, Lemcke G (2001) Loss on ignition as a method for estimating organic and carbonate content in sediments: reproducibility and comparability of results. J Paleolimnol 25:101-110

Herrera-Silveira JA (1996) Salinity and nutrients in a tropical coastal lagoon with groundwater discharges to the Gulf of Mexico. Hydrobiologia 321:165-176

Herrera-Silveira JA, Morales-Ojeda SM (2009) Evaluation of the health status of a coastal ecosystem in southeast Mexico: assessment of water quality, phytoplankton and submerged aquatic vegetation. Mar Pollut Bull 59: $72-86$

Herrera-Silveira JA, Teutli HC, Zaldívar JA, Pérez CR, Alvarado E, Caamal-Sosa, Morales OS (2009) Programa regional para la caracterización y el monitoreo de ecosistemas de manglar del Golfo de México y el Caribe Mexicano: inicio de una red multi-institutcional. Península de Yucatán. CINVESTAV-ECOPEY/CONABIO, FB1307-N009/08. 2ndo Informe Parcial. CONABIO, Mexico City

Holguin G, Gonzalez-Zamorano P, De-Bashan LE, Mendoza R, Amador E, Bashan Y (2006) Mangrove health in an arid environment encroached by urban development-a case study. Sci Total Environ 363:260-274

Lefebvre G, Poulin B (1996) Seasonal abundance of migrant birds and food resources in Panamanian mangrove forests. Wilson Bull 108:748-759

Lovelock CE, Feller IC, Adame MF, Reef R, Penrose HM, Wei L, Ball MC (2011) Intense storms and the delivery of materials that relieve nutrient limitations in mangroves of an arid zone estuary. Funct Plant Biol 38:514-522

Lugo AE, Snedaker SC (1974) The ecology of mangroves. Annu Rev Ecol Syst 5:39-64

Maron JL, Estes JA, Croll DA, Danner EM, Elmendorf SC, Buckelew SL (2006) An introduced predator alters Aleutian Islands plant communities by thwarting nutrient subsidies. Ecol Monogr 76:3-24

Marra PP, Hobson KA, Holmes RT (1998) Linking winter and summer events in a migratory bird by using stablecarbon isotopes. Science 282:1884-1886

McKee KL, Feller IC, Popp M, Wanek W (2002) Mangrove isotopic $\left(\delta^{15} \mathrm{~N}\right.$ and $\left.\delta^{13} \mathrm{C}\right)$ fractionation across a nitrogen vs. phosphorus limitation gradient. Ecology 83: 1065-1075

McKee KL, Cahoon DR, Feller IC (2007) Caribbean mangroves adjust to rising sea level through biotic controls

Editorial responsibility: Erik Kristensen,

Odense, Denmark on change in soil elevation. Glob Ecol Biogeogr 16: 545-556

> Nagelkerken I, Blaber SJM, Bouillon S, Green P and others (2008) The habitat function of mangroves for terrestrial and marine fauna: a review. Aquat Bot 89:155-185

Onuf CP, Teal JM, Valiela I (1977) Interactions of nutrients, plant growth and herbivory in a mangrove ecosystem. Ecology 58:514-526

Parsons TR, Maita Y, Lalli CM (1984) A manual of chemical and biological methods for seawater analysis. Pergamon Press, New York, NY

Perry E, Paytan A, Pedersen B, Velazquez-Oliman G (2009) Groundwater geochemistry of the Yucatan Peninsula, Mexico: constraints on stratigraphy and hydrogeology. J Hydrol 367:27-40

Polis GA, Hurd SD (1996) Linking marine and terrestrial food webs: allochthonous input from the ocean supports high secondary productivity on small islands and coastal land communities. Am Nat 147:396-423

Polis GA, Anderson WB, Holt RD (1997) Toward an integration of landscape and food web ecology: the dynamics of spatially subsidized food webs. Annu Rev Ecol Syst 28: 289-316

Powell GV, Fourqurea JW, Kenworthy W, Zieman JC (1991) Bird colonies cause seagrass enrichment in a subtropical estuary: observational and experimental evidence. Estuar Coast Shelf Sci 32:567-579

Robertson AI, Alongi DM (1992) Tropical mangrove ecosystems. American Geophysical Union, Washington, DC

> Schmidt S, Dennison WC, Moss GJ, Stewart R (2004) Nitrogen ecophysiology of Heron Island, a subtropical coral cay of the Great Barrier Reef, Australia. Funct Plant Biol 31:517-528

Sekercioglu CH (2006) Increasing awareness of avian ecological function. Trends Ecol Evol 21:464-471

Smith TJ, Whelan KRT (2006) Development of allometric relations for three mangrove species in South Florida for use in the Greater Everglades ecosystem restoration. Wetl Ecol Manag14:409-419

Wainright SC, Haney JC, Kerr C, Golovkin N, Flint MV (1998) Utilization of nitrogen derived from seabird guano by terrestrial and marine plants at St. Paul, Pribilof Islands, Bering Sea, Alaska. Mar Biol 131:63-71

Wooller M, Smallwood B, Jacobson M, Fogel M (2003) Carbon and nitrogen stable isotopic variation in Laguncularia racemosa (L .) (white mangrove) from Florida and Belize: implications for trophic level studies. Hydrobiologia:13-23

Zaldívar-Jiménez A, Herrera-Silveira J, Coronado-Molina C, Alonzo-Parra D (2004) Estructura y productividad de los manglares en la reserva de biosfera Ría Celestún, Yucatán, México. Madera y Bosques 2:25-35

Submitted: June 3, 2014; Accepted: January 12, 2015

Proofs received from author(s): March 20, 2015 